Transportation 7 (1978) 19-33

(c) Elsevier Scientific Publishing Company, Amsterdam - Printed in the Netherlands

\title{
FACTORS INFLUENCING DESTINATION CHOICE FOR THE URBAN GROCERY SHOPPING TRIP
}

\author{
WILFRED W. RECKER* \\ Institute of Transportation Studies and School of Engineering and School of \\ Social Sciences, University of California, Irvine \\ LIDIA P. KOSTYNIUK \\ Department of Civil Engineering, The University of Michigan
}

\begin{abstract}
Destination choice for the urban grocery shopping trip is hypothesized to be determined by three factors: the individual's perception of the destination, the individual's accessibility to the destination and the relative number of opportunities to exercise any particular choice. Results of a multinomial logit model estimation support this hypothesis and provide useful information concerning the role of urban form in this destination choice situation. It is determined that accessibility is the primary aspect influencing destination choice and that its effect is nonlinear.
\end{abstract}

\section{Introduction}

The primary purpose of this study is to evaluate the relative importances of consumer preferences, accessibility and opportunity in determining the destination choice of an individual for a particular activity - that of shopping for major grocery items. The investigation focused on this activity as the most frequent repetitive urban trip (constituting approximately $15 \%$ of total person trips, as reported by Burnett, 1973) with relatively unconstrained end points. While the most frequent urban trip, the home based work trip, accounts for $40 \%$ of all urban person trips, its destination is usually totally fixed by the individual's employment.

Recent attempts to model shopping behavior have focused on behavioral approaches employing linear learning theory and attitudinal choice theory. Attitudinal models of shopping behavior have, with few exceptions (Burnett, 1973, 1974), been variations of the Fishbein attitudinal model (Fishbein, 1972), and have focused primarily on the prediction of preferences or attitudes using multiple regression techniques.

*On leave 1977-78 from State University of New York at Buffalo, Buffalo, New York 14214. 
While disaggregate methodologies have been applied successfully to choice models in the field of urban transportation research (McFadden, 1968, 1973; Lerman and Ben-Akiva, 1975; Burns et al., 1975) and in a few cases have also been applied to attitudinal data (Hartgen, 1974; Constantino et al., 1974; Recker and Golob, 1976; Recker and Stevens, 1976), these analyses have almost exclusively been concerned with modal choice.

In this paper results of a disaggregate model of urban residents' grocery shopping destination choice behavior are presented and the relative importances of the individuals' perceptions of the destinations, the individuals' perceptions of the accessibilities of the stores and the number of opportunities available in that choice decision are assessed.

\section{Analysis}

To investigate the importances of the various aspects assumed to be determinant to an individual's destination choice for major grocery shopping, it is hypothesized that the decision process of the individual is rational, based on the utility that alternative selections hold for the individual. It is further hypothesized that the utility of a particular destination for grocery shopping is primarily a function of three influences: (1) the individual's attitudes toward the store and its operation, (2) the individual's perception of his or her accessibility to the destination and (3) the number of opportunities available to the individual to exercise his or her selection of a particular alternative.

Information on these three aspects of the assumed decision process and on actual individual behavior was collected from an attitudinal mail-out survey sent to a random sample of 1500 households in six areas of Buffalo, N.Y., selected on the basis of demographic information. Approximately 300 completed questionnaires were returned.

The households were chosen by a two-stage random sampling method. The city blocks in each of the six areas were enumerated. From this a set of blocks for each area was chosen randomly. The households on these blocks were then enumerated and a set of these was selected randomly for each area.

Data on the survey respondents' perceptions of each of the grocery stores they frequented (up to 4 in number) were collected in the form of responses to semantic differential rating tasks on a comprehensive set of attributes used to describe the store (see Fig. 1). In all cases the respondent was "the member of the household who does most of the grocery shopping."

To simplify the response patterns of the sample the respondents' ratings were factor analyzed using principal components analysis [1] (Harman, 1967) followed by varimax orthogonal rotation (Kaiser, 1958). Four factors were retained, accounting for about $60 \%$ of the total variance in respondents' 


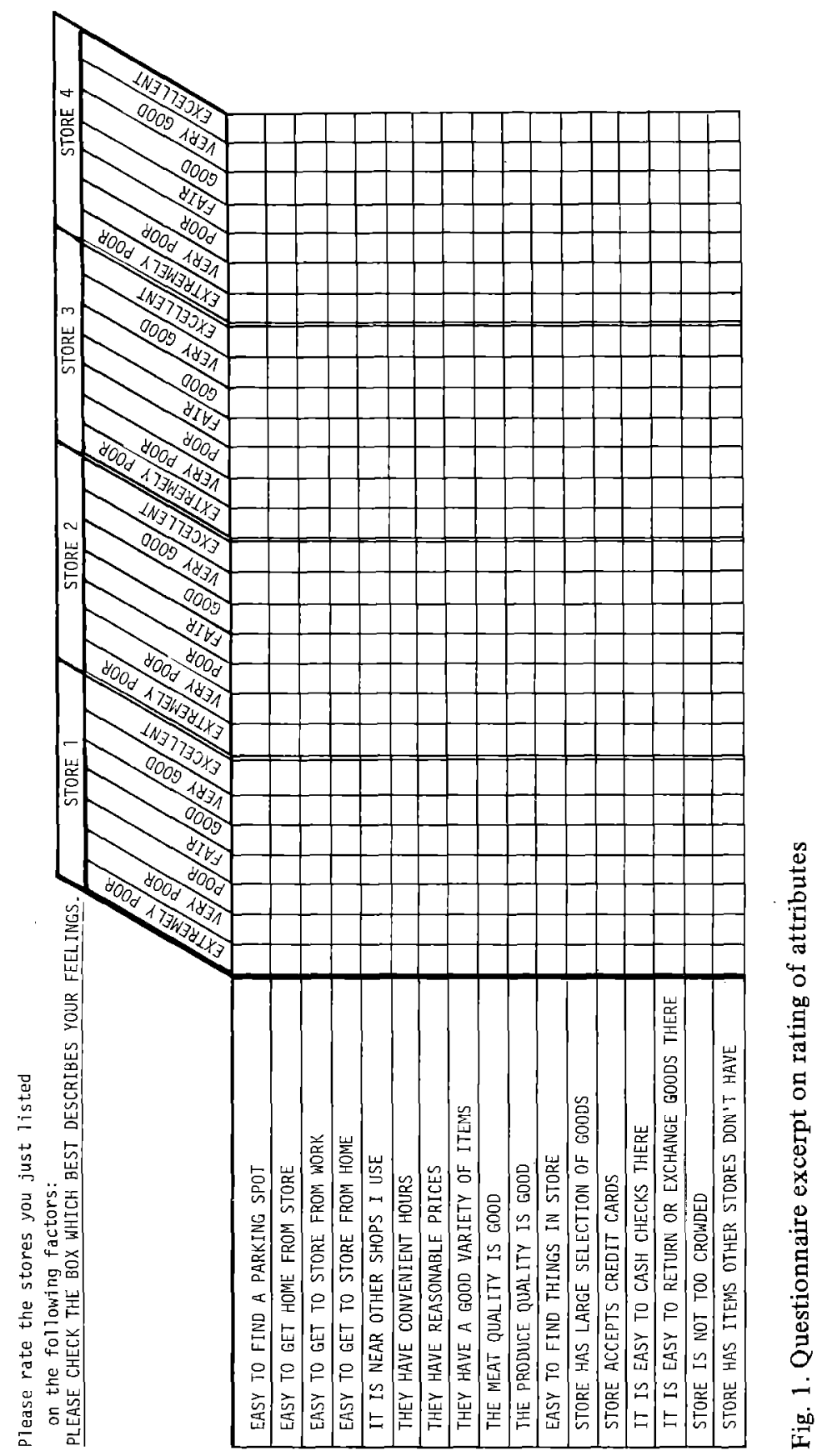


ratings of the attributes. These latent dimensions of perception are interpreted as follows (see Table 1): Factor 1 (QUALITY) involves attributes of the stores that measure the relative quality and variety of the items offered by the store; it is essentially a measure of the product. Factor 2 (ACCESSIBILITY) is concerned only with the ease of completing the trip required to obtain the product. Whereas Factor 2 can be thought of as measuring the inconvenience of the trip to the store, Factor 3 (CONVENIENCE) represents a dimension corresponding to the inconveniences associated with the actual shopping activity at the store. Factor 4 (SERVICE) is a measure of services provided by the store which are related to method of payment.

TABLE 1

STORE FACTORS

$($ SAMPLE SIZE $=860)$

\begin{tabular}{|c|c|c|c|}
\hline $\begin{array}{c}\text { FACTOR DESCRIPTION } \\
(\% \text { VARIANCE EXPLAINED) }\end{array}$ & $\begin{array}{c}\text { ATTRIBUTES INCLUDED } \\
\text { IN FACTOR }\end{array}$ & $\begin{array}{r}\text { FACTOR } \\
\text { LOADING } \\
\end{array}$ & COMMUNAL ITY \\
\hline $\begin{array}{l}\text { QUAL ITY } \\
(19 \%)\end{array}$ & $\begin{array}{l}\text { REASONABLE PRICES } \\
\text { VARIETY OF ITEMS } \\
\text { MEAT QUALITY } \\
\text { PRODUCE QUALITY } \\
\text { SELECTION OF GOODS } \\
\text { HAS ITEMS OTHER STORES DON'T }\end{array}$ & $\begin{array}{l}.50 \\
.77 \\
.65 \\
.81 \\
.72 \\
.68\end{array}$ & $\begin{array}{l}.57 \\
.76 \\
.52 \\
.66 \\
.71 \\
.49\end{array}$ \\
\hline $\begin{array}{l}\text { ACCESSIBILITY } \\
(15 \%)\end{array}$ & $\begin{array}{l}\text { EASE OF GETTING HOME FROM STORE } \\
\text { EASE OF GETTING TO STORE FROM WORK } \\
\text { EASE OF GETTING TO STORE FROM HOME }\end{array}$ & $\begin{array}{l}.87 \\
.77 \\
.87\end{array}$ & $\begin{array}{l}.81 \\
.62 \\
.80\end{array}$ \\
\hline $\begin{array}{l}\text { CONVENIENCE } \\
(11 \%)\end{array}$ & $\begin{array}{l}\text { PARKING FACILITIES } \\
\text { NEAR OTHER SHOPS } \\
\text { CONVENIENT HOURS } \\
\text { EASE OF FINDING ITEMS IN STORE } \\
\text { CROWDING IN STORE }\end{array}$ & $\begin{array}{l}.59 \\
.51 \\
.37 \\
.41 \\
.80\end{array}$ & $\begin{array}{l}.51 \\
.31 \\
.41 \\
.49 \\
.69\end{array}$ \\
\hline $\begin{array}{l}\text { SERVICE } \\
(15 \%)\end{array}$ & $\begin{array}{l}\text { ACCEPTANCE OF CREDIT CARDS } \\
\text { CHECK CASHING } \\
\text { EASE OF RETURNING GOODS }\end{array}$ & $\begin{array}{l}.80 \\
.77 \\
.55\end{array}$ & $\begin{array}{l}.66 \\
.64 \\
.50\end{array}$ \\
\hline
\end{tabular}

To gain some information on the relative merits of attitudinal measures vs. individual perceptions of traditional objective measures for predicting traveler behavior, a second measure of the respondent's accessibility to each store he or she frequented was obtained in the form of his or her perception of the time required for the trip to each store (as well as the return travel time, if different) and the mode of travel.

Specification of the destination choice set is highly dependent on the nature of the information desired from the study. Over 150 different stores were frequented by the respondents. And while it is entirely possible to manageably specify a utility-type choice model with that large number of alternative choices (provided that the estimated utility weights are not alternative specific) [2], the information gained from such a model would be likely to be more useful to the market researcher than to the urban transportation planner. To be of use to the urban planner, model results must be interpretable in terms of their consequences on the structure of urban form. For 
this reason, each store mentioned in the survey was classified according to various criteria (see Table 2) into categories that are easily identifiable components of the urban environment:

Type 1: Supermarket in a shopping plaza;

Type 2: Free-standing supermarket;

Type 3: Small, free-standing self-service market (less than 4 checkouts);

Type 4: Neighborhood market (non self-service, no checkouts);

Type 5: Discount department store/supermarket.

TABLE 2

SYSTEM DIFFERENCES BY WHICH STORES WERE CLASSIFIED

\begin{tabular}{|c|c|c|c|c|c|c|}
\hline TYPE & $\begin{array}{c}\text { SELF } \\
\text { SERVICE }\end{array}$ & LOCATION & $\begin{array}{l}\text { PARKING } \\
\text { LOT }\end{array}$ & $\begin{array}{c}\text { AVG. NO. } \\
\text { OF } \\
\text { CHECKOUT } \\
\text { COUNTERS }\end{array}$ & $\begin{array}{c}\text { SHOPPING } \\
\text { CARTS }\end{array}$ & MERCHANDISE \\
\hline 1 & YES & $\begin{array}{l}\text { IN LARGE } \\
\text { SHOPPING } \\
\text { CENTER }\end{array}$ & LARGE & 6 & YES & $\begin{array}{l}\text { FOOD \& } \\
\text { STAPLES }\end{array}$ \\
\hline 2 & YES & $\begin{array}{c}\text { FREE } \\
\text { STANDING } \\
\text { OR IN SMALL } \\
\text { SHOPPING } \\
\text { CENTER }\end{array}$ & LARGE & 6 & YES & $\begin{array}{l}\text { FOOD \& } \\
\text { STAPLES }\end{array}$ \\
\hline 3 & YES & $\begin{array}{c}\text { FREE } \\
\text { STANDING }\end{array}$ & $\begin{array}{c}\text { SMALL } \\
\text { OR NONE }\end{array}$ & 2 & USUALLY & $\begin{array}{l}\text { FOOD \& } \\
\text { STAPLES }\end{array}$ \\
\hline 4 & NO & $\begin{array}{c}\text { FREE } \\
\text { STANDING }\end{array}$ & $\begin{array}{l}\text { USUALLY } \\
\text { NONE }\end{array}$ & 0 & NO & $\begin{array}{l}\text { FOOD \& } \\
\text { STAPLES }\end{array}$ \\
\hline 5 & YES & $\begin{array}{c}\text { FREE } \\
\text { STANDING }\end{array}$ & LARGE & 10 & YES & GENERAL \\
\hline
\end{tabular}

A measure of the opportunity of each survey respondent to select a store of any particular type was developed as the relative number of stores of that type that could be reached by the respondent within a prescribed time interval by the respondent's usual travel mode. Time intervals of 5,10 , and 15 minutes were used in these calculations; the latter figure representing an observed maximum time for grocery shopping trips applicable to over $90 \%$ of the study sample.

To determine the effects of the individuals' attitudes, accessibility and opportunity in selecting a destination for grocery shopping, a multinomial logit choice model (see McFadden, 1968 and 1973 for a detailed deviation) was estimated. The dependent variable in the model is the probability that an individual will select a store of a particular type as his or her most frequent location for major grocery shopping. The independent variables in the model are: (1) the individual's attitudes toward the QUALITY, CONVENIENCE and SERVICE aspects of each store frequented by the individual; (2) the individual's ACCESSIBILITY to each store, specified either in terms of the ACCESSIBILITY dimension identified through the factor analysis of respondents' attitudes or as the respondent's stated travel time to the store; and 
(3) the OPPORTUNITY for selecting a store of each type, specified in terms of the ratio of the number of stores of a particular type within a prescribed travel time interval of the individual to the total number of stores of all types within that travel time interval.

\section{Interpretation of Results}

The utility weights (coefficients) associated with the hypothesized five elements (QUALITY, CONVENIENCE, SERVICE, ACCESSIBILITY and OPPORTUNITY) of this destination choice were estimated, using maximum likelihood techniques, for series of cases designed to demonstrate the relative importances of these elements.

The set of relevant alternatives for each shopper consisted of only the stores of different types where the individual actually shopped. The alternative chosen was defined as the type of the store where the individual shopped most frequently. Observations where the shopper shopped at only one store, at stores of the same type, or at stores of different types but with the same frequency, were not used in the model estimations, leaving a usable sample size of 172 individuals.

The QUALITY, CONVENIENCE and SERVICE dimensions are represented in the models by that variable in each respective factor which tested most significant using the values of the t-statistic as criteria. On this basis, the perceptions of the QUALITY and CONVENIENCE factors of each store were represented by the respondent's ratings of the variety of goods in the store and with the uncrowded condition of the store, respectively. The SERVICE factor was represented by the rating on check cashing service.

The selection of the time intervals (i.e., 5, 10, or 15 minutes) to be used in the final models as a basis for the OPPORTUNITY component was determined on a trial basis with the values of the t-statistic as criteria.

A constant was assigned to store types 1 and 5 . These stores were different from the others in that they were close to non-grocery shopping opportunities. Store type 1 was a supermarket in a large plaza, which is a collection of stores, and store type 5 was a large discount store with grocery and non-grocery departments. The selection of this particular assignment of the constant was also due, in part, to a trial process of examining the model results of many different assignments.

In the models presented only variables with estimated coefficients which tested significantly different from zero at the .05 level based on a one-tailed $t$ test were included in the estimation.

In the first model estimated, the ACCESSIBILITY dimension is represented by the respondent's stated travel time to the stores. The results of this estimation are summarized in Table 3.1. In this and in the other models 
tested two measures are reported as indicators of model performance. The first measure, the ratio of choices predicted correctly, is the ratio of the number of times the predicted probability of the chosen alternative was greater than that of a non-chosen relevant alternative to the total number of choices made by the sample. This measure was also categorized by the alternative chosen to better identify strengths and weaknesses of the models.

The second measure, the ratio of individuals predicted correctly, is the ratio of the number of individuals for which the predicted probability of the chosen alternative was greater than that of every other relevant alternative to the total number of individuals in the sample.

Of the factors identified as descriptors of stores, only SERVICE is not significant in choice of type of store. In the estimation, no variable contained in the SERVICE factor had an estimated coefficient that was significantly different from zero at the $95 \%$ confidence level.

Only opportunity measures associated with store types 1 and 3 are significant in the model and both are defined by 15-minute time contours. That opportunity measures for the remaining store types (supermarkets, neighborhood markets and discount department stores) are not significant in determining destination choice indicates that having such stores readily available to the individuals in this sample is no guarantee of patronage. Rather, the decision to choose these latter locations for a major grocery shopping trip is more dependent on the specific attributes of the particular store than in the case of the former types (supermarkets in shopping plazas and small self-service supermarkets) where the decision is significantly influenced by the sheer number (density) of such stores proximate to home. The decision to shop at the former locations is thus more conscious than that to shop at the latter which is, to a greater extent, a reaction to the environment. Hints toward possible explanations for this may lie in the types of areas indicated by extremes in the magnitudes of these opportunity measures. A high opportunity ratio for stores of type 1 (i.e., supermarkets in shopping plazas) is usually associated with areas near major arterials and densely populated suburban fringe business districts. In these areas, opportunities for combined trips are great and the decision to shop at a particular location may be influenced by the density of other related shopping opportunities in the area. A high opportunity ratio for stores of type 3 (i.e., small self-service supermarkets) can be associated with older, more traditionally defined neighborhood areas, in which numerous such small supermarkets have developed on small parcels of vacated land imbedded in a tightly constrained physical environment. As such they are part and parcel of a "neighborhood" lifestyle.

The significance of the constant indicates that, as expected, there are additional dimensions associated with store types 1 and 5 that are not accounted for by the variables included in the model. These unrepresented 
dimensions most probably are associated with the variety of non-food commodities available at store types 1 and 5 and by inherent complexities of the multi-purpose and multi-stop trips associated with these destinations. Even with the added constant the predictive performance of the model relative to store types 1 and 5 is poor compared to its performance in predicting choice of types 2,3 , and 4 .

To measure the overall sensitivities of choice probabilities to uniform changes in explanatory variables for all individuals in the sample, aggregate elasticities (see Recker and Golob, 1976) were estimated for the choice model summarized in Table 3.1. These elasticities are shown in Table 3.2.

From the estimations of the elasticities of the QUALITY factor it can be expected that store types 1 and 5 (i.e., supermarket in a shopping plaza and discount department store/supermarket, respectively) would benefit most by improving the QUALITY dimension of their operations. For store type 1 , for example, a ten percent increase in individuals' perception of the

TABLE 3.1

LOGIT MODEL VERSION 1-CHOICE OF TYPE OF STORE

\begin{tabular}{|c|c|c|c|}
\hline FACTOR & VARIABLE & COEFFICIENT & $T$ \\
\hline QUALITY & $\begin{array}{l}\text { RATING OF VARIETY OF } \\
\text { GOODS IN STORE }\end{array}$ & 0.286 & 2.62 \\
\hline CONVENIENCE & $\begin{array}{l}\text { RATING OF UNCROWDED } \\
\text { CONDITION OF STORE }\end{array}$ & 0.203 & 2.27 \\
\hline SERVICE & $\begin{array}{l}\text { RATING OF CHECK } \\
\text { CASHING SERVICES OF } \\
\text { STORE }\end{array}$ & ---- & $-\cdots$ \\
\hline ACCESSIBILITY & TRAVEL TIME TO STORE & -0.445 & $-3.19^{5}$ \\
\hline \multirow{4}{*}{ OPPORTUNITY } & $\begin{array}{l}\text { NUMBER OF TYPE I } \\
\text { OPPORTUNITIES WITHIN } \\
15 \text { MINUTES }\end{array}$ & \multirow[b]{2}{*}{3.972} & \multirow{2}{*}{2.56} \\
\hline & $\begin{array}{l}\text { NUMBER OF ALL } \\
\text { OPPORTUNITIES. WITHIN } \\
15 \text { MINUTES }\end{array}$ & & \\
\hline & $\begin{array}{l}\text { NUMBER OF TYPE } 3 \\
\text { OPPORTUNITIES WITHIN } \\
\text { I5 MINUTES } \\
\end{array}$ & \multirow[b]{2}{*}{2.436} & \multirow[b]{2}{*}{2.49} \\
\hline & $\begin{array}{l}\text { NUMBER OF ALL } \\
\text { OPPORTUNITIES WITHIN } \\
15 \text { MINUTES }\end{array}$ & & \\
\hline $\begin{array}{l}\text { CONSTANT ASSIGNED } \\
\text { TO STORE TYPES } \\
1 \text { AND } 5\end{array}$ & & -.945 & -4.22 \\
\hline
\end{tabular}

RATIO OF CHOICES PREDICTED CORRECTLY $=.71$ RATIO OF INDIVIDUALS PREDICTED CORRECTLY $=.66$

\begin{tabular}{|c|c|c|}
\hline STORE TYPE & $\begin{array}{c}\text { PERCENT OF } \\
\text { TIMES CHOSEN }\end{array}$ & $\begin{array}{r}\text { RATIO OF CHOICES } \\
\text { PREDICTED CORRECTLY }\end{array}$ \\
\hline 1 & 17.8 & .29 \\
\hline 2 & 41.6 & .73 \\
\hline 3 & 30.4 & .95 \\
\hline 4 & 9.3 & .70 \\
\hline 5 & 0.9 & .00 \\
\hline
\end{tabular}


TABLE 3.2

AGGREGATE ELASTICITIES FOR LOGIT CHOICE MODEL-VERSION

\begin{tabular}{|c|c|c|c|c|c|c|c|c|c|c|c|}
\hline \multirow{2}{*}{ FACTOR } & \multirow{2}{*}{ VARIABLE } & \multicolumn{10}{|c|}{ STORE } \\
\hline & & ELAST. & $\begin{array}{l}\text { CR0SS- } \\
\text { ELAST. }\end{array}$ & ELAST. & $\begin{array}{l}\text { CROSS- } \\
\text { ELAST. }\end{array}$ & ELAST. & $\begin{array}{l}\text { CROSS- } \\
\text { ELAST. }\end{array}$ & ELAST. & $\begin{array}{l}\text { CROSS- } \\
\text { ELAST. }\end{array}$ & ELAST. & $\begin{array}{l}\text { CROSS- } \\
\text { ELAST. }\end{array}$ \\
\hline QUALITY & $\begin{array}{l}\text { RATING OF VARIETY OF } \\
\text { GOODS IN STORE }\end{array}$ & .60 & -.99 & .29 & -1.25 & .34 & -1.19 & .42 & -.93 & .71 & -1.01 \\
\hline CONVENIENCE & $\begin{array}{l}\text { RATING OF UNCROWDED } \\
\text { CONDITION OF STORE }\end{array}$ & .32 & -.55 & .19 & -.72 & .25 & -.80 & .36 & -.64 & .39 & -.51 \\
\hline ACCESS IBILITY & TRAVEL TIME TO STORE & -.35 & .59 & -.16 & .69 & -.16 & .46 & -.23 & .36 & -.61 & .55 \\
\hline \multirow{3}{*}{ OPPORTUNITY } & $\begin{array}{l}\text { NUMMER OF TYPE } ~ \\
\text { 0?PORTUNITIES WITHIN } \\
15 \text { MINUTES }\end{array}$ & .23 & -.61 & --- & $-\cdots-$ & -- & --- & $\ldots$ & -- & -- & ---- \\
\hline & $\begin{array}{l}\text { NUMBER OF TYPE } 3 \\
\text { OPPORTUNITIES WITHIN } \\
15 \text { MINUTES } \\
\end{array}$ & \multirow[b]{2}{*}{---} & \multirow[b]{2}{*}{$-\cdots$} & \multirow[b]{2}{*}{---} & \multirow[b]{2}{*}{----} & \multirow[b]{2}{*}{.15} & \multirow[b]{2}{*}{-.69} & \multirow[b]{2}{*}{$\ldots$} & \multirow[b]{2}{*}{---} & \multirow[b]{2}{*}{--} & \multirow[b]{2}{*}{----} \\
\hline & $\begin{array}{l}\text { NUMBER OF ALL } \\
\text { OPPORTUNITIES WITHIN } \\
15 \text { MINUTES }\end{array}$ & & & & & & & & & & \\
\hline
\end{tabular}

QUALITY dimension can be expected to lead to a $6 \%$ increase in the probability of shopping there most frequently, while for store type 5 such an increase would lead to over a $7 \%$ increase in the probability. The remaining store types are relatively insensitive to changes in this factor. All of the crosselasticities associated with the QUALITY dimension have a value of about -1 , indicating that each store type can be expected to be affected in a similar manner due to changes in a competitor's QUALITY.

The OPPORTUNITY measures have elasticities associated with only those specific store types to which they are assigned. These elasticities, and those associated with the CONVENIENCE factor, are relatively low indicating that the choice probabilities can be expected to be relatively insensitive to changes in the number of stores of a given type in an area or to changes along the convenience dimension. Since the SERVICE factor was not included in the model, no elasticities are associated with this dimension.

The elasticities associated with the ACCESSIBILITY dimension, as expected, indicate that choice of the type 5 stores (discount department store/supermarket) is much more sensitive to travel time than are the other types. In the area surveyed these stores are typically located in the outer suburbs. Also sensitive to ACCESSIBILITY are the type 1 stores (supermarket in a shopping center) which are typically located on the fringes of the residential areas. The store types associated with locations in residential areas appear to be insensitive to ACCESSIBILITY.

A clear understanding of the interactions among QUALITY, CONVENIENCE and ACCESSIBILITY as they relate to this destination choice, as well as the effect of urban structure on these interactions, is contained in these elasticity measures. If the store types are ordered according to area 
served ranging from neighborhood to regional (i.e., type 4 , type 3 , type 2 , type 1, type 5), there is a general trend of increasing value of ACCESSIBILITY relative to that of QUALITY. While, for all store types, changes in ACCESSIBILITY are expected to result in smaller changes in destination frequencies than are comparable changes in QUALITY, such trade-offs become more equitable as accessibility to the destination decreases. For example, the effect on choice probabilities of a $10 \%$ increase in travel time to a neighborhood market can be offset by approximately a 5\% increase in perception of the QUALITY dimension of the store. The much less accessible discount department store/supermarket requires about a $9 \%$ increase in perception of QUALITY to balance a $10 \%$ increase in travel time. The nonlinear nature of the disutility of travel is clearly evidenced by these results.

A similar comparison between the ACCESSIBILITY and CONVENIENCE elasticities indicates that choice of shopping destinations typically outside the neighborhood (i.e. at supermarkets in shopping plazas and at large discount department stores) is more sensitive to changes in ACCESSIBILITY than to CONVENIENCE aspects. For example, increases of about $16 \%$ and $11 \%$ in perceptions of CONVENIENCE of large discount department stores and supermarkets in shopping plazas, respectively, can be expected to counterbalance a $10 \%$ increase in travel times to these stores. For shopping destinations that typically are within the neighborhood (i.e. supermarkets, small self-service markets and neighborhood markets) the reverse trend holds, i.e. choice is more sensitive to convenience aspects than to those of ACCESSIBILITY. In the case of neighborhood markets, for example, a $10 \%$ increase in travel time is offset by only about a $6 \%$ increase in perception of QUALITY.

\section{Sensitivity of Results to Model Specification}

To evaluate the sensitivity of the model to variations in the basic hypothesis, three additional model specifications were tested. In the first variation, the OPPORTUNITY component of the hypothesized utility function was deleted. The results of the estimation of this model, containing only the attitudinal and ACCESSIBILITY components, are shown in Table 4.1. This deletion caused minor decreases only in cases in which store types 1 or 3 were selected. The overall predictive power of the model remains virtually unchanged, indicating that the influence of the "number of targets" on this destination choice situation is considerably less than that of more rational decision processes. Substitution of the attitudinal counterpart to "travel time to store" as the ACCESSIBILITY component led to almost total deterioration of the model's ability to correctly predict choice of supermarkets in shopping plazas (see Table 4.2.) A detailed inspection of the data 
TABLE 4.1

LOGIT MODEL VERSION 2-CHOICE OF TYPE OF STORE WITH OBJECTIVE MEASURE REPRESENTING "ACCESSIBILITY"

\begin{tabular}{|c|c|c|c|}
\hline FACTOR & VARIABLE & COEFFICIENT & $\mathrm{T}$ \\
\hline QUAL ITY & $\begin{array}{l}\text { RATING OF VARIETY OF } \\
\text { GOODS IN STORE }\end{array}$ & 0.256 & 2.36 \\
\hline CONVENIENCE & $\begin{array}{l}\text { RATING OF UNCROWDED } \\
\text { CONDITION OF STORE }\end{array}$ & 0.209 & 2.34 \\
\hline SERVICE & $\begin{array}{l}\text { RATING OF CHECK } \\
\text { CASHING SERVICES OF } \\
\text { STORE }\end{array}$ & ---- & --- \\
\hline ACCESSIBILITY & TRAVEL TIME TO STORE & -0.578 & -4.22 \\
\hline \multirow{4}{*}{ OPPORTUNITY } & $\begin{array}{l}\text { NUMBER OF TYPE } 1 \\
\text { OPPORTUNITIES WITHIN } \\
15 \text { MINUTES }\end{array}$ & \multirow{2}{*}{--- } & \multirow{2}{*}{---} \\
\hline & $\begin{array}{l}\text { NUMBER OF ALL } \\
\text { OPPORTUNITIES WITHIN } \\
15 \text { MINUTES }\end{array}$ & & \\
\hline & $\begin{array}{l}\text { NUMBER OF TYPE } 3 \\
\text { OPPORTUNITIES WITHIN } \\
15 \text { MINUTES } \\
\end{array}$ & \multirow[b]{2}{*}{$-\cdots-$} & \multirow{2}{*}{$\ldots$} \\
\hline & $\begin{array}{l}\text { NUMBER OF ALL } \\
\text { OPPORTUNITIES WITHIN } \\
15 \text { MINUTES }\end{array}$ & & \\
\hline $\begin{array}{l}\text { CONSTANT ASSIGNED } \\
\text { TO STORE TYPES } \\
1 \text { AND } 5\end{array}$ & & -0.481 & -2.18 \\
\hline
\end{tabular}

RATIO OF CHOICES PREDICTED CORRECTLY $=.70$ RATIO OF INDIVIDUALS PREDICTED CORRECTLY $=.66$

\begin{tabular}{|c|c|c|}
\hline STORE TYPE & $\begin{array}{c}\text { PERCENT OF } \\
\text { TIMES CHOSEN }\end{array}$ & $\begin{array}{r}\text { RATIO } \\
\text { PREDICTED OF CHOICES }\end{array}$ \\
\hline 1 & 17.8 & .21 \\
\hline 2 & 41.6 & .80 \\
\hline 3 & 30.4 & .86 \\
\hline 4 & 9.3 & .70 \\
\hline 5 & 0.9 & .00 \\
\hline
\end{tabular}

for respondents selecting this type of store revealed that while the respondents' mean perception of travel time to this type of store was between that associated with free-standing supermarkets and that corresponding to large discount department stores, their mean rating of ease of getting home from such stores was the lowest of all types of stores. This indicates that the subjective rating for ACCESSIBILITY contains information that is significantly different from that contained in perceptions of travel time, a fact also evidenced by the vastly different $t$-scores associated with the two variables. From the analysis of the data it is reasonable to conclude that the subjective rating of "ease of getting home from store" is significantly influenced by the nature of the travel (e.g. congestion levels, number of intersections, etc.) as well as by the actual travel time. That travel time is a better predictor (in this model) of destination choice may indicate that the subjective rating is mediated by the individuals' expectations prior to being translated into actual 
TABLE 4.2

LOGIT MODEL VERSION 3-CHOICE OF TYPE OF STORE

WITH SUBJECTIVE RATING REPRESENTING "ACCESSIBILITY"

\begin{tabular}{|c|c|c|c|}
\hline FACTOR & VARIABLE & COEFFICIENT & T \\
\hline QUAL ITY & $\begin{array}{l}\text { RATING OF VARIETY OF } \\
\text { GOODS IN STORE }\end{array}$ & 0.211 & 2.13 \\
\hline CONVENIENCE & $\begin{array}{l}\text { RATING OF UNCROWDED } \\
\text { CONDITION OF STORE }\end{array}$ & 0.187 & 2.16 \\
\hline SERVICE & $\begin{array}{l}\text { RATING OF CHECK } \\
\text { CASHING SERVICES OF } \\
\text { STORE }\end{array}$ & ---- & --- \\
\hline ACCESSIBILITY & $\begin{array}{l}\text { RATING OF EASE OF } \\
\text { GETTING HOME FROM } \\
\text { STORE }\end{array}$ & 0.207 & 1.88 \\
\hline \multirow{4}{*}{ OPPORTUNITY } & $\begin{array}{l}\text { NUMBER OF TYPE } 1 \\
\text { OPPORTUNITIES WITHIN } \\
15 \text { MINUTES }\end{array}$ & \multirow{2}{*}{---} & \multirow{2}{*}{----} \\
\hline & $\begin{array}{l}\text { NUMBER OF ALL } \\
\text { OPPORTUNITIES WITHIN } \\
15 \text { MINUTES }\end{array}$ & & \\
\hline & $\begin{array}{l}\text { NUMBER OF TYPE } 3 \\
\text { OPPORTUNITIES WITHIN } \\
15 \text { MINUTES } \\
\end{array}$ & \multirow[b]{2}{*}{$-\cdots$} & \multirow{2}{*}{---} \\
\hline & $\begin{array}{l}\text { NUMBER OF ALL } \\
\text { OPPORTUNITIES WITHIN } \\
15 \text { MINUTES }\end{array}$ & & \\
\hline $\begin{array}{l}\text { CONSTANT ASSIGNED } \\
\text { TO STORE TYPES } \\
1 \text { AND } 5\end{array}$ & & -0.682 & -3.22 \\
\hline
\end{tabular}

RATIO OF CHOICES PREDICTED CORRECTLY $=.68$ RATIO OF INDIVIDUALS PREDICTED CORRECTLY $=.66$

\begin{tabular}{|c|c|c|}
\hline STORE TYPE & $\begin{array}{c}\text { PERCENT OF } \\
\text { TIMES CHOSEN }\end{array}$ & $\begin{array}{c}\text { RATIO OF CHOICES } \\
\text { PREDICTED CORRECTLY }\end{array}$ \\
\hline 1 & 17.8 & .05 \\
\hline 2 & 41.6 & .87 \\
\hline 3 & 30.4 & .82 \\
\hline 4 & 9.3 & .65 \\
\hline 5 & 0.9 & .00 \\
\hline
\end{tabular}

choice. To be treated as anything more than conjecture, such an hypothesis requires thorough testing beyond this limited study.

Finally, to obtain some feel for the added information on choice of store type behavior provided by the individuals' perceptions of the stores' attributes, a model in which only the ACCESSIBILITY and OPPORTUNITY components of choice were represented was estimated [3]. These results are shown in Table 5. While the prediction ratios for this model remain high, the dissaggregate ratios indicate some shifts in predictive power associated with the removal of the preference term. A detailed inspection of the disaggregated sample showed that most of this shift was concentrated among respondents who, according to the model in Table 3.1, had utilities that were in the highly elastic range of the sigmoid curve defined by the logit function. The loss in explanatory power is primarily associated with cases in which loca- 
TABLE 5

LOGIT CHOICE MODEL VERSION 4-CHOICE OF TYPE OF STORE WITH ONLY "ACCESSIBILITY" AND "OPPORTUNITY" INCLUDED

\begin{tabular}{|c|c|c|c|}
\hline FACTOR & VARIABLE & COEFFICIENT & $T$ \\
\hline QUALITY & $\begin{array}{l}\text { RATING OF VARIETY OF } \\
\text { GOODS IN STORE }\end{array}$ & $-\cdots$ & --- \\
\hline CONVENIENCE & $\begin{array}{l}\text { RATING OF UNCROWDED } \\
\text { CONDITION IN STORE }\end{array}$ & --- & --- \\
\hline SERVICE & $\begin{array}{l}\text { RATING OF CHECK } \\
\text { CASHING SERVICES OF } \\
\text { STORE }\end{array}$ & $---\infty$ & ---- \\
\hline ACCESSIBILITY & TRAVEL TIME TO STORE & -0.386 & -2.86 \\
\hline \multirow{4}{*}{ OPPORTUNITY } & $\begin{array}{l}\text { NUMBER OF TYPE } 1 \\
\text { OPPORTUNITIES WITHIN } \\
15 \text { MINUTES }\end{array}$ & \multirow{2}{*}{3.674} & \multirow[b]{2}{*}{2.45} \\
\hline & $\begin{array}{l}\text { NUMBER OF ALL } \\
\text { OPPORTUNITIES WITHIN } \\
15 \text { MINUTES }\end{array}$ & & \\
\hline & $\begin{array}{l}\text { NUMBER OF TYPE } 3 \\
\text { OPPORTUNIT IES WITHIN } \\
15 \text { MINUTES }\end{array}$ & \multirow[b]{2}{*}{2.034} & \multirow[b]{2}{*}{2.31} \\
\hline & $\begin{array}{l}\text { NUMBER OF ALL } \\
\text { OPPORTUNITIES WITHIN } \\
15 \text { MINUTES }\end{array}$ & & \\
\hline $\begin{array}{l}\text { CONSTANT ASSIGNED } \\
\text { TO STORE TYPES } \\
1 \text { AND } 5\end{array}$ & & -.931 & -4.28 \\
\hline
\end{tabular}

RATIO OF CHOICES PREDICTED CORRECTLY $=70$ RATIO OF INDIVIDUALS PREDICTED CORRECTLY $=.66$

\begin{tabular}{|c|c|c|}
\hline STORE TYPE & $\begin{array}{c}\text { PERCENT OF } \\
\text { TIMES CHOSEN }\end{array}$ & $\begin{array}{c}\text { RATIO OF CHOICES } \\
\text { PREDICTED CORRECTLY }\end{array}$ \\
\hline 1 & 17.8 & .24 \\
\hline 2 & 41.6 & .69 \\
\hline 3 & 30.4 & .95 \\
\hline 4 & 9.3 & .85 \\
\hline 5 & 0.9 & .00 \\
\hline
\end{tabular}

tions of type 1 or 2 were selected. These are precisely the locations where trade-offs between travel time and the utility of the destination are expected to be most active. Locations of type 4 (neighborhood markets), on the other hand, are so accessible to a significant number of respondents that chose this type that perceived negative aspects of QUALITY and CONVENIENCE of these stores only served to confound this choice for these respondents. These results tend to reinforce conclusions brought out by the elasticity measures regarding possible nonlinearities in the utility specification.

\section{Conclusions}

Destination choice for the urban grocery shopping trip has been hypothesized to be the result of three influences: the individual's perception of the destination, the individual's accessibility to the destination, and the rela- 
tive number of opportunities to exercise any particular choice. Results of analysis of the variance-covariance structure of data on the individual's attitudes toward various types of stores indicate that a common set of factors exists for the various types of stores considered. Representation of these factors, together with supply-side information in a multinomial logit model formulation, has been shown to give accurate results in predicting choice from among several different alternatives, and statistical tests verify the basic hypothesis. The results evidence a complex relationship between the structure of urban form and destination choice that is only crudely approximated by the usual assumptions of linear additive utility models. Accessibility is the primary factor in determining store destination choice for this sample population, and its influence is probably nonlinear or, perhaps, threshold-like.

The results of this investigation point toward the need for much additional research into the interrelationship of urban form and individual travel decision behavior. Such research must question the nature of this interrelationship before any true understanding of complex travel decisions, such as destination choice, can be expected.

\section{Notes}

1. The number of factors retained was determined by a comparison of the set of eigenvalues obtained from an analysis of the actual correlations with a set of eigenvalues obtained from analyses of random data matrices of the same order as the actual data matrices.

2. In the multinomial logit model, for example, estimation is based on utility comparisons among alternatives relevant to the individual, irrespective of each specific alternative, requiring only identification of which alternative is the chosen alternative.

3. A model in which only the attitudinal components were represented was also estimated, but the results were not statistically reliable.

\section{References}

Burnett, K. P. (1973): "Disaggregate Behavioral Models: Travel Decisions Other Than Destination Choice," Proceedings of Engineering Foundation Conference. "Issues in Behavioral Travel Demand and the Valuation of Travel Time," South Berwick, Maine.

Burnett, K. P., (1974). "A Bernoulli Model of Destination Choice," presented at the 53rd Annual Meeting of the Transportation Research Board, in Transportation Research Record 527.

Burns, L. D., T. F. Golob, and G. C. Nicolaidis, (1975). "A Theory of Urban Households' Automobile Ownership Decisions," presented at the 54th Annual Meeting of the Transportation Research Board, in Transportation Research Record 569.

Constantino, D. P., T. F. Golob, and P. R. Stopher (1974). "Consumer Preferences for Automated Public Transportation Systems," presented at the 53rd Annual Meeting of the Transportation Research Boatd, in Transportation Research Record 527. 
Fishbein, M. (1972). "The Search for Attitudinal-Behavioral Consistency," in Joel B. Cohen, ed., Behavioral Science Foundations of Consumer Behavior, New York: The Free Press.

Harman, H. H. (1967). Modern Factor Analysis, University of Chicago Press.

Hartgen, D. T. (1974). "Attitudinal and Situational Variables Influencing Urban Mode Choice," Transportation 3: 377-392.

Kaiser, H. F. (1958), "The Varimax Criterion for Analytic Rotation in Factor Analysis," Psychometrika 23.

Lerman, S. R. and M. Ben-Akiva (1975). "Disaggregate Behavioral Model of Automobile Ownership," presented at the 54th Annual Meeting of the Transportation Research Board, in Transportation Research Record 569.

McFadden, D. (1968). "The Revealed Preferences of a Government Bureaucracy," Department of Economics, University of California, Berkeley.

McFadden, D. (1973). "Conditional Logit Analysis of Qualitative Choice Behavior," in P. Zarembka, ed. Frontiers in Econometrics. New York: Academic Press.

Recker, W. W. and T. F. Golob (1976). "An Attitudinal Modal Choice Model," Transportation Research 6.

Recker, W.W. and R.F. Stevens (1976). "Attitudinal Models of Modal Choice: The Multinomial Case for Selected Non-Work Trips," Transportation 5: 355-376. 